\title{
Short Communication: Infanticide of Javan slow loris (Nycticebus javanicus) in captivity
}

\author{
PANGDA SOPHA SUSHADI, WIRDATETI, NI LUH PUTU RISCHA PHADMACANTY, \\ MOHAMAD WAHYUDIN \\ Zoology Division, Research Center for Biology, Indonesian Institute of Sciences. Jl. Raya Jakarta-Bogor Km. 46, Cibinong, Bogor 16911, West Java, \\ Indonesia. Tel.: +62-21-87907604, `email: teti_mzb@yahoo.com,pang001@lipi.go.id
}

Manuscript received: 13 January 2021. Revision accepted: 4 February 2021.

\begin{abstract}
Sushadi DS, Phadmacanty NLPR, Wahyudin M, Wirdateti 2021. Short Communication: Infanticide of Javan slow loris (Nycticebus javanicus) in captivity. Biodiversitas 22: 1606-1611. Over the past decade, the population of Javan slow loris (Nycticebus javanicus) in the wild has continued to decline. Various conservation efforts by the government and NGOs have been carried out, but still have not yielded significant results. Many studies have highlighted the impact of poaching and forestland conversion as a cause, but the natural behavior of $N$. javanicus, especially infant care interactions, is poorly studied. We investigated the case of a 5-day-old Javan slow loris baby named Monda, found dead in captivity. Monda was born in captivity and impounded with its mother and an adult male. She was found dead decapitated with a sign of injury on the right arm. Microscopic fecal examination of the other lorises showed hair and bone fragments in the male feces. Based on this finding, it is possible that infanticide also occurs in slow lorises in its natural habitat but may have been underreported.
\end{abstract}

Keywords: Behavior, cannibalism, captivity, infanticide, Nycticebus javanicus

\section{INTRODUCTION}

Infanticide is the predominant cause of infant mortality in more than 50 primate species (Palombit 2015) and becomes even more crucial for threatened animals. With a low reproduction rate, along with distress in their habitat, the negligence of the parent in raising the baby to continue the survival of the species is a big loss. Javan slow loris (Nycticebus javanicus), which since 2008 has the status of Critically Endangered (Nekaris et al. 2020) and is in CITES Appendix 1, are also at risk of this threat. As an endemic animal of Java island, its population continues to decline (Nekaris and Starr 2015), thus comprehensive studies as an effort to save it are very urgent to do. However, there is a potential for maladaptive behavior, such as infanticide, which has been recorded in some primate species (Opie et al. 2013). Both the parent itself and other males have been recorded as having infanticides, such as in Saguinus fuscicollis and S. mystax (Culot et al. 2011).

In general, slow lorises are solitary nocturnal animals. Despite being solitary, slow lorises form a stable intrafamily social unit, called spatial group. The spatial group of $N$. javanicus usually consists of one male, one female, and up to 3 younger individuals, but might vary. During the day, one spatial group usually occupies a bamboo tree as a sleeping group and sleeps close to each other (Winarti 2011; Wirdateti 2012). For their night activities, the same group will share overlapping space in the same home range. Adult males will usually separate themselves, while the mother is always carrying the infant. Thus, $N$. javanicus is categorized as solitary animals living in groups (Wiens 2002; Winarti 2011). Interactions in a spatial group were seen to be positive, such as allogrooming, following, pant-growling, and click-calling. However, only $3 \%$ of their active time is spent in spatial groups. This evidence may suggest a social monogamous system, despite polyandrous activity has also been reported (Wiens 2002; Wiens and Zitzmann 2003).

Nycticebus javanicus is threatened by deforestation and wildlife trade, which includes exotic pet trade, traditional medicine, and bushmeat (Nekaris and Jaffe 2007), while their reproduction rate is low. With 188 days of gestation period (Izard et al. 1988), these species give birth to an average of only one offspring a year. Weaning ages range from 3-4 months, but a new offspring will be completely independent at about 20 months of age. During these times, infant care is fully carried out by the mother and the male is not involved, thus the survival of the infant is fully its mother responsibility (Wiens and Zitzmann 2003).

Infant care interactions in primates are fundamental, given that as an altricial creature infant primates need full parental care at birth (Blumberg and Sokoloff 1998). Unlike precocious animals, infant primates are either left in their nests or carried by their parent (Ross 2001). The parent is fully responsible for meeting feed needs, guarding against predators, and teaching survival skills when entering the weaning age (Izard 2006). Although some species show biparental care patterns in infant rearing (Storey and Zeigler 2016), most of the time it is mother's responsibility (Maestripieri 2001). In prosimians, particularly N. javanicus, maternal care is predominant (Izard 2006). This means that negligence of the mother in caring for its infant could be fatal. 
Based on conditions in the field, N. javanicus is one of the most demanded animals for illegal poaching (Nekaris and Starr 2015). Apart from being in great demand as pets, on Java, these animals are considered to have mystical powers. Many people use $N$. javanicus limbs such as bones and skull as amulets and black magic (Nijman and Nekaris 2014). Moreover, they are also widely hunted and burnedalive for "minyak kukang" (loris oil), a potion believed to give mystical power to attract the opposite sex in humans (Gardiner 2019). Therefore, when a dead N. javanicus is found decapitated or with incomplete limbs, people generally assume it was died as a sacrifice and associate it with black magic. Yet it is possible that the death was caused by cannibalism such as infanticide, given that its predators such as snakes and eagles rarely leave the carcasses of their prey (Hawkeswood 2017). However, only a study could provide an answer to this hypothesis.

We present a case study of a $N$. javanicus infant who died while being kept in captivity with its mother and another adult male. Necropsy was carried out to reveal the cause of death, as well as microscopic fecal examination to observe a gut content of other lorises. If it is proven that the infant died as a result of cannibalism, it might provide a new perspective on the possibility of something similar happening in in-situ populations. The factors identified as the cause could also be eliminated in the future, both in exsitu and in-situ conservation.

\section{MATERIALS AND METHODS}

\section{Animal maintenance and collection of the carcass}

Female $N$. javanicus baby named Monda was captivedborn in good health on October 23, 2019. She was captived in Bhumisatwa experimental facility, Research Center for Biology-LIPI, along with her mother and another adult male from different spatial group who was captured from same location in the wild in June 2019. The pregnancy is undiscovered at the first encounter and the two adults intendedly placed together for other ex-situ research purposes. The enclosure has been designed with additional enrichment according to the natural habitat of the slow loris and is protected from the presence of other animals.

Monda's birth was unexpected and since another enclosure still needs to be prepared before she and her mother can move, they were continuously kept together with the male. Monda and her mother occupy a different resting box apart from the male. The feed given consisted of fruits and crickets, followed feed intake standard for non-human primates (Rothman et al. 2012). Since her birth, the mother was observed breastfeeding and grooming her, same behavior as described by Fitch-Snyder and Ehrlich (2003) on N. bengalensis and N. pygmaeus.

Five days later, on October 28 in the morning, Monda was found dead decapitated (Figure 1). The previous day, no changes in behavior were observed from Monda, her mother, or the male. Monda's carcass was then collected and stored in a freezer for necropsy the next day.

\section{Procedures for necropsy and fecal examination}

Necropsy was carried out on October 30, 2019 by following the non-human primate necropsy protocol (Blanchard and Russell-Lodrigue 2012). Inspection and measurement of all organs were performed, unless for the head region. The anatomical pathology of the organs was presented descriptively to analyze the cause of Monda's death.

Fecal examination was also performed on the mother and the adult male. The two were kept in separate cages after Monda's death, then each feces were sampled for two consecutive days. Sampled feces was then diluted with water and examined for the presence of hair and bone fragments microscopically. Identification of the animal species was then carried out on the hair and bone fragments found in the feces.
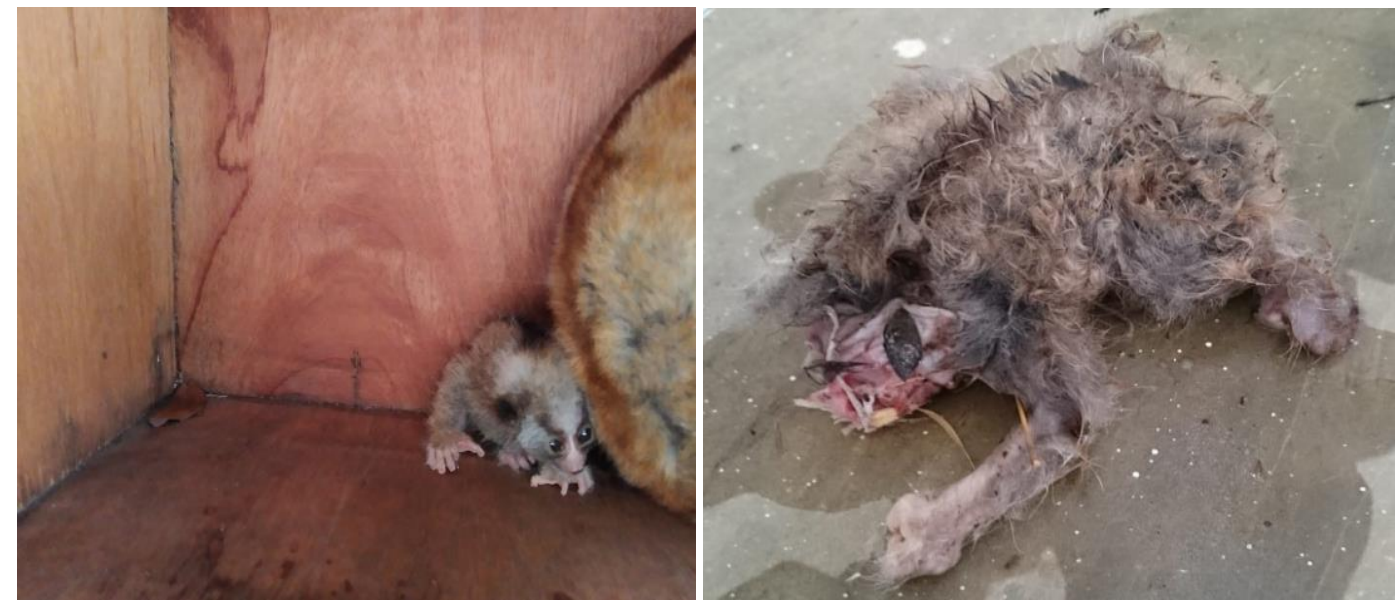

Figure 1. Monda with her mother in their resting box (up); and Monda's carcass (down) 


\section{RESULTS AND DISCUSSION}

General condition examination revealed that the head, as well as the skull, were missing, with hemorrhagic lesions and hyperemia at the distal of the neck muscles. The atlas bone on the cervical spine is missing, so we only able to observe from the axis bone to the distal of the body. There was also severe inflammation along the right arm which indicated Monda's resistance prior to her death. No pathological findings were observed in any organs other than the head (Mcaloose and Stalis 2011) which indicates all the organs are in good health. Some of measured organ parameters are shown in Table 1 and the results of necropsy are presented in Table 2.

Based on inspection of the neck, the head injury was thought to be due to predatory behavior from other animals. Given that the enclosure is fenced and has a concrete floor, which is preventing predators to enter, we suspected that Monda died as a result of cannibalistic behavior by her mother or the adult male, thus we confirm it by examining their feces. Under normal circumstances, their feces should not contain anything other than fruit or crickets. Follow-up examination on the feces of the adult male showed that there were mammalian hairs and bone fragments identified as Monda's (Figure 2), while nothing suspicious found in the mother. This finding confirmed the infanticidal behavior of the adult male.

Cannibalism is often found in almost every animal taxon and its most common form is infanticide (Nishimura 2010). In principle, intraspecific infanticide, especially in wild animals, can be carried out by males or females who are or are not genetically related to the infant (Hrdy 2016). Filial infanticide by mother is most likely occurs when the infant is born with a defect that likely will disrupt its future development (Lukas and Huchard 2019) as recorded in Felidae family (Packer 2001). However, based on the necropsy results, Monda's physical and organs condition were good and did not appear to have any pathological conditions. On the other hand, recorded cases of male infanticide in primates have also been reported (Opie et al. 2013).

More specific causes of infanticide are also summarized in Ramsay et al. (2020) into four hypotheses: limited resources, exploitation, maladaptive behavior, and sexual selection (Dixson 2012). High competition for limited resources, such as food or shelter, is the motive for the first hypothesis (Hrdy 1979). In primates, it has bigger chance to occur in species with high population density, as recorded in chimpanzees (Pan troglodytes) (Townsend et al. 2007) and spider monkeys (Ateles hybridus) (Rimbach et al. 2012). This perhaps could also be associated to the exploitation hypothesis, where infanticide is carried out for the purpose of nutritional benefit (Van Schaik and Van Noordwijk 2019) since it is not only reduced competition for resources, but also serves as the source of feeding for the executor. However, these two hypotheses are unlikely to occur in this case since there are unlimited resources in captivity with adequate food and shelter. Also, only small part of the head was consumed, which made little sense if exploitation was the motive. The same applies to maladaptive behavior hypothesis which emphasizes distress due to human disturbance in their habitat as a cause of infanticide. The enclosure was isolated and far enough from human disturbance. There were also restrictions on access and addition of appropriate enrichments provided to ensure the welfare of the animals that apparently do not support this hypothesis.

The last one, sexual selection, is a hypothesis that puts the male as the executor (Manguette et al. 2019). It suggests that males kill infants to force the mother back into her estrus cycle again, thus giving the male the opportunity to sire the next offspring (Van Schaik and Van Noordwijk 2019). In this hypothesis, the male is not predicted to have genetic relationship to the infant, as demonstrated on colobus monkeys (Colobus vellerosus) (Teichroeb and Sicotte 2008) and golden snub-nosed monkeys (Rhinopithecus roxellana) (Yao et al. 2016), Hanuman langurs (Semnopithecus entellus) (Heistermann et al. 2001), and mountain gorilla (Gorilla beringei beringei) (Robbins et al. 2013). Infanticide of Monda is likely in accordance with this since the male is not related. Also, it is suggested that $N$. javanicus are likely non-seasonal breeders (Wiens and Zitzmann 2003), so the effort to kill the infant might give a benefit to the male to sire the mother's next offspring.

So far, studies of slow loris behavior in in-situ habitats have not found any cannibalistic or infanticide behavior (Kappeler et al. 2017) and no record on ex-situ studies. The study by Rode-Margono et al. (2014) showed that $N$. javanicus almost never socializes in the wild and spends most of its time sleeping and looking for food. However, there have been several findings of slow loris carcasses by the villagers, mostly defective without head or limbs (Nijman and Nekaris 2014). This finding is believed by them to be part of black magic activities using slow lorises, although there was also no evidence that the death was caused by humans (Nekaris et al. 2013). While infanticide is very difficult to directly observe and might be underreported to date, our result just encourages that this behavior is possible to occur in this species.

Table 1. Length and weight of Monda's organs

\begin{tabular}{lcc}
\hline \multicolumn{1}{c}{ Indicator } & Length $(\mathbf{m m})$ & Weight $(\mathbf{g})$ \\
\hline SVL (total body length) & 93.5 & \\
Circumference (abdomen) & 11.9 & \\
Chest size & 16.7 & \\
Femur & 28.9 & \\
Tibia & 33.5 & \\
Metatarsal & 23.6 & \\
Humeral & 29.3 & \\
Radial-Ulnar & 29.1 & \\
Metacarpal & 12.4 & \\
Neck & 9.5 & \\
Stomach & Diameter $=11.7$ & Emptied $=0.39$ \\
& Length $=20.1$ & \\
Liver & 29.5 & 0.44 \\
Heart & 17 & 0.57 \\
Lung & 24.8 & Left $=0.21$ \\
Kidneys & Left $=10$ & \\
& Right $=9$ & \\
Duodenum & 187 & \\
Jejunum & 208 & \\
Ileum & 193 & \\
Uterus & 12 & \\
\end{tabular}


Table 2. Necropsy results of Monda with gross lesions and diagnoses

\begin{tabular}{|c|c|c|c|}
\hline Regions & Organs & Gross Lesions & Diagnoses \\
\hline Outer Body & $\begin{array}{l}\text { Hair and skin } \\
\text { Mucous membrane } \\
\text { Eyes } \\
\text { Ears }\end{array}$ & $\begin{array}{l}\text { No lesions } \\
\text { N/A } \\
\text { N/A } \\
\text { N/A }\end{array}$ & \\
\hline Subcutaneous & Fat & No lesions & \\
\hline Lymph Node & $\begin{array}{l}\text { Ln. Mandibularis } \\
\text { Ln. Retropharyngealis } \\
\text { Ln. Prescapularis } \\
\text { Ln. Axillaris } \\
\text { Ln. Femoralis } \\
\text { Ln. Poplitea }\end{array}$ & $\begin{array}{l}\text { N/A } \\
\text { N/A } \\
\text { No lesions } \\
\text { No lesions } \\
\text { No lesions } \\
\text { No lesions }\end{array}$ & \\
\hline Thoracic Cavity & Negative pressure & Present, no lesions & \\
\hline Respiratory Tract & $\begin{array}{l}\text { Sinuses } \\
\text { Pharynx } \\
\text { Larynx } \\
\text { Trachea } \\
\text { Bronchus } \\
\text { Lungs }\end{array}$ & $\begin{array}{l}\text { N/A } \\
\text { N/A } \\
\text { N/A } \\
\text { No lesions } \\
\text { No lesions } \\
\text { No lesions }\end{array}$ & \\
\hline Digestive Tract & $\begin{array}{l}\text { Mouth cavity } \\
\text { Tongue } \\
\text { Oesophagus } \\
\text { Gastric } \\
\text { Small intestine } \\
\text { Large intestine } \\
\text { Ln. Mesenterica } \\
\text { Pancreas } \\
\text { Liver } \\
\text { Ln. Hepatica }\end{array}$ & $\begin{array}{l}\text { N/A } \\
\text { N/A } \\
\text { N/A } \\
\text { Feeded, no lesions } \\
\text { Feeded, no lesions } \\
\text { Feeded, no lesions } \\
\text { Pale, exudative } \\
\text { Pale } \\
\text { No lesions } \\
\text { No lesions }\end{array}$ & $\begin{array}{l}\text { Autolysis } \\
\text { Autolysis }\end{array}$ \\
\hline Circulatory Tract & $\begin{array}{l}\text { Heart } \\
\text { Blood vessels }\end{array}$ & $\begin{array}{l}\text { No lesions } \\
\text { No lesions }\end{array}$ & \\
\hline Lymphoreticular System & $\begin{array}{l}\text { Thymus } \\
\text { Spleen }\end{array}$ & $\begin{array}{l}\text { No lesions } \\
\text { No lesions }\end{array}$ & \\
\hline Urogenital Tract & $\begin{array}{l}\text { Kidneys } \\
\text { Ureter } \\
\text { Bladder } \\
\text { Ovaries } \\
\text { Uterus } \\
\text { Vagina }\end{array}$ & $\begin{array}{l}\text { No lesions } \\
\text { No lesions } \\
\text { No lesions } \\
\text { No lesions } \\
\text { No lesions } \\
\text { No lesions }\end{array}$ & \\
\hline Central Nerve System & Brain & N/A & Vulnus morsum \\
\hline Locomotive System & $\begin{array}{l}\text { Bones } \\
\text { Joints }\end{array}$ & $\begin{array}{l}\text { - Hyperemia and hemorrhage on } \\
\text { the neck } \\
\text { - Hyperemia and edema on right } \\
\text { radius-ulna to metacarpus } \\
\text { No lesions } \\
\text { No lesions }\end{array}$ & Inflammation \\
\hline
\end{tabular}

Note: Some organs on the head are not applicable for a visual inspection (N/A) 

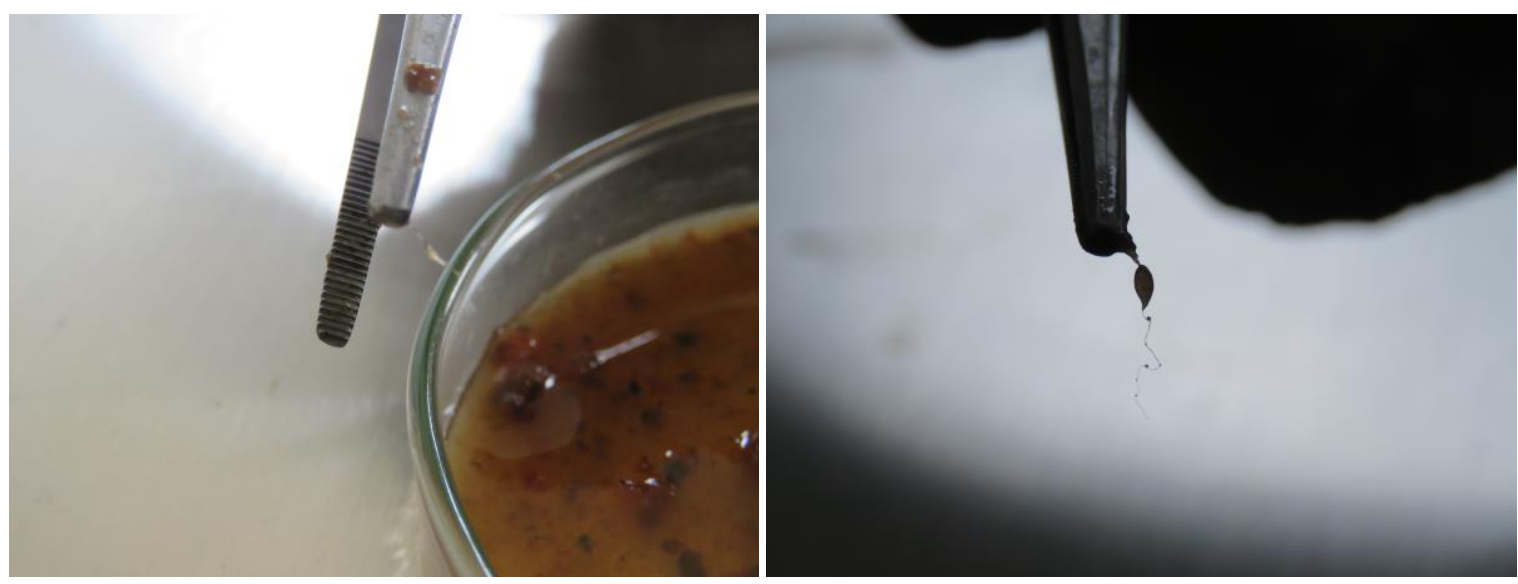

Figure 2. Hair (left) and bone fragment (right) of slow loris found in the adult male feces

However, although our result supports sexual selection hypothesis, further motives might be driven by the incident of infanticide in wild populations. Deforestation of their habitats and massive human activity around them could be the stressors. Long-term monitoring in wild populations and further studies such as metabolomic analysis of feces on a group population of $N$. javanicus to determine their feed preferences, may provide answers to this conjecture. It is also important for ex-situ management to always pay attention to the mating system. In addition, measure of cortisol level as an initial screening before the animals enter the enclosure would be very useful as it could be used as a stress indicator later (Nugraha et al. 2017). Given that one individual of $N$. javanicus is known to have a territory of no less than 30 hectares with a range of up to $2 \mathrm{~km}$ per day (Rode-Margono et al. 2014), the condition on captivity might be quite contrasted and could be lead to stereotypic behavior (Lutz 2014), which might be present as cannibalism behavior (Moore et al. 2015). Matsumoto et al. (2018) also suggest that poor environmental conditions could be the cause of filial cannibalism.

\section{ACKNOWLEDGEMENTS}

This work was funded by DIPA for CITES Program 2019, Research Center for Biology, LIPI, Bogor, Indonesia. PSS, W, and NLPRP are equally contributed to this work.

\section{REFERENCES}

Blanchard JL, Russell-Lodrigue KE. 2012. Biosafety in laboratories using nonhuman primates. In: Nonhuman (eds). Primates in Biomedical Research. $2^{\text {nd }}$ ed. Elsevier, Amsterdam. DOI: 10.1016/B978-0-12381365-7.00018-2.

Blumberg MS, Sokoloff G. 1998. Thermoregulatory competence and behavioral expression in the young of altricial species - revisited. Dev Psychobiol 33 (2): 107-123. DOI: 10.1002/(SICI)1098-2302 (199809)33:2<107::AID-DEV2>3.0.CO;2-N.

Culot L, Lledo-Ferrer Y, Hoelscher O, Lazo FJJM, Huynen MC, Heymann EW. 2011. Reproductive failure, possible maternal infanticide, and cannibalism in wild Moustached tamarins, Saguinus mystax. Primates 52 (2): 179-186. DOI: 10.1007/s10329-011-0238-6.
Dixson AF. 2012. Primate sexuality: Comparative studies of the prosimians, monkeys, apes, and humans. In: Primate Sexuality: Comparative Studies of the Prosimians, Monkeys, Apes, and Humans. 2nd ed. Oxford University Press, UK. DOI: 10.1093/acprof:osobl/9780199544646.001.0001.

Fitch-Snyder H, Ehrlich A. 2003. Mother-infant interactions in slow lorises (Nycticebus bengalensis) and Pygmy lorises (Nycticebus pygmaeus). Folia Primatol 74 (5-6): 259-271. DOI: 10.1159/000073313.

Gardiner M. 2019. A brief assessment of minyak kukang (Slow loris oil). Canopy 20 (1): 25-29.

Hawkeswood TJ. 2017. Attempted predation on a captive specimen of the Sunda slow loris, Nycticebus coucang (Boddaert, 1785) (Mammalia: Lorisidae) by the Golden tree snake, Chrysopelea ornata (Shaw, 1802) (Reptilia: Colubridae) at Phuket, Southern Thailand, with a review of some published Thailand locality records for $C$. ornata. Calodema 580: 1-6.

Heistermann M, Ziegler T, Van Schaik CP, Launhardt K, Winkler P, Hodges JK. 2001. Loss of oestrus, concealed ovulation and paternity confusion in free-ranging Hanuman langurs. Proc Royal Soc B 268 (1484): 2445-2451. DOI: 10.1098/rspb.2001.1833.

Hrdy SB. 1979. Infanticide among animals: A review, classification, and examination of the implications for the reproductive strategies of females. Ethol Sociobiol 1: 13-40. DOI: 10.1016/0162-3095 (79)90004-9.

Hrdy SB. 2016. Variable postpartum responsiveness among humans and other primates with "cooperative breeding": A comparative and evolutionary perspective. Horm Behav 77: 272-283. DOI: 10.1016/j.yhbeh.2015.10.016.

Izard MK. 2006. Nursery-reared prosimian primates. In: Sackett GP, Ruppentahal GC, Elias K (eds). Nursery Rearing of Nonhuman Primates in the 21st Century. 1st ed. Springer, US.

Izard MK, Weisenseel KA, Ange RL. 1988. Reproduction in the slow loris (Nycticebus coucang). Am J Primatol 16 (4): 331-339. DOI: 10.1002/ajp.1350160405.

Kappeler PM, Cuozzo FP, Fichtel C, Ganzhorn JU, Gursky-Doyen S, Irwin MT, Ichino S, Lawler R, Nekaris KAI, Ramanamanjato JB, Radespiel U, Sauther ML, Wright PC, Zimmermann E. 2017. Longterm field studies of lemurs, lorises, and tarsiers. J Mammal 98 (3): 661-669. DOI: 10.1093/jmammal/gyx013.

Lukas D, Huchard E. 2019. The evolution of infanticide by females in mammals. Phil Trans R Soc Lond B Biol Sci 374 (1780): 20180075. DOI: $10.1098 /$ rstb.2018.0075.

Lutz CK. 2014. Stereotypic behavior in nonhuman primates as a model for the human condition. ILAR J 55 (2): 284-296. DOI: 10.1093/ilar/ilu016.

Maestripieri D. 2001. Is there mother-infant bonding in primates? Dev Rev 21 (1): 93-120. DOI: 10.1006/drev.2000.0522.

Manguette ML, Robbins AM, Breuer T, Stokes EJ, Parnell RJ, Robbins MM. 2019. Intersexual conflict influences female reproductive success in a female-dispersing primate. Behav Ecol Sociobiol 73 (9). DOI: $10.1007 / \mathrm{s} 00265-019-2727-3$. 
Matsumoto Y, Tateishi T, Terada R, Soyano K, Takegaki T. 2018. Filial cannibalism by male fish as an infanticide to restart courtship by selfregulating androgen levels. Curr Biol 28 (17): 2831-2836. DOI: 10.1016/j.cub.2018.06.056.

Mcaloose D, Stalis IH. 2011. Prosimians. In: Pathology of Wildlife and Zoo Animals. Elsevier, Amsterdam. DOI: 10.1016/B978-0-12 805306-5/00013-4

Moore RS, Cabana F, Nekaris KAI. 2015. Factors influencing stereotypic behaviours of animals rescued from Asian animal markets: A slow loris case study. Appl Anim Behav Sci 166 (1): 131-136. DOI 10.1016/j.applanim.2015.02.014.

Nekaris KAI, Jaffe S. 2007. Unexpected diversity of slow lorises (Nycticebus spp.) within the Javan pet trade: Implications for slow loris taxonomy. Contrib Zool 76 (3): 187-196. DOI: 10.1163/18759866-07603004.

Nekaris KAI, Moore RS, Rode EJ, Fry BG. 2013. Mad, bad and dangerous to know: The biochemistry, ecology and evolution of slow loris venom. J Venom Anim Toxins Incl Trop Dis 19 (1): 1-10. DOI: 10.1186/1678-9199-19-21.

Nekaris KAI, Starr CR. 2015. Conservation and ecology of the neglected slow loris: Priorities and prospects. Endanger Species Res 28 (1): 87 95. DOI: 10.3354/esr00674.

Nekaris KAI, Shekelle M, Wirdateti, Rode-Margono EJ, Nijman V. 2020 Nycticebus javanicus. The IUCN Red List of Threatened Species 2020: e.T39761A86050473. DOI: 10.2305/IUCN.UK.2020 2.RLTS.T39761A86050473.

Nijman V, Nekaris KAI. 2014. Traditions, taboos and trade in slow lorises in sundanese communities in Southern Java, Indonesia. Endanger Species Res 25 (1): 79-88. DOI: 10.3354/esr00610.

Nishimura K. 2010. Kleptoparasitism and cannibalism BT - encyclopedia of animal behavior. In: Encyclopedia of Animal Behavior. $2^{\text {nd }}$ ed. Elsevier, Nederland.

Nugraha TP, Heistermann M, Agil M, Purwantara B, Supriatna I, Gholib G, van Schaik CP, Weingrill T. 2017. Validation of a field-friendly extraction and storage method to monitor fecal steroid metabolites in wild orangutans. Primates 58 (2): 285-294. DOI: 10.1007/s10329 016-0583-6.

Opie C, Atkinson QD, Dunbar RIM, Shultz S. 2013. Male infanticide leads to social monogamy in primates. Proc Natl Acad Sci USA 110 (33): 13328-13332. DOI: 10.1073/pnas.1307903110.

Packer C. 2001. Infanticide is no fallacy. Am Anthropol 102 (4): 829-857. DOI: 10.1093/analys/31.6.177.

Palombit RA. 2015. Infanticide as sexual conflict: coevolution of male strategies and female counterstrategies. Cold Spring Harb Perspect Biol 7 (6): 1-31. DOI: 10.1101/cshperspect.a017640.

Ramsay MS, Morrison B, Stead SM. 2020. Infanticide and partial cannibalism in free-ranging Coquerel's sifaka (Propithecu coquereli). Primates 61 (4): 575-581. DOI: 10.1007/s10329-02000828-z.
Rimbach R, Pardo-Martinez A, Montes-Rojas A, Di Fiore A, Link A 2012. Interspecific infanticide and infant-directed aggression by Spider monkeys (Ateles hybridus) in a fragmented forest in Colombia. Am J Primatol 74 (11): 990-997. DOI: 10.1002/ajp.22052.

Robbins AM, Gray M, Basabose A, Uwingeli P, Mburanumwe I. 2013. Impact of male infanticide on the social structure of Mountain gorillas. PLoS ONE 8 (11): 78256 DOI: 10.1371/journal.pone.0078256.

Rode-Margono EJ, Nijman V, Wirdateti, Nekaris KAI. 2014. Ethology of the critically endangered Javan slow loris Nycticebus javanicus É . Geoffroy Saint-Hilaire in West Java. Asian Primates 4 (2): 27-38.

Ross C. 2001. Park or ride? evolution of infant carrying in primates. International J. Primatol. 22 (5): 749-771. DOI: 10.1023/A:1012065332758.

Rothman JM, Chapman CA, van Soest PJ. 2012. Methods in primate nutritional ecology: A user's guide. Int J Primatol 33 (3): 542-566. DOI: $10.1007 / \mathrm{s} 10764-011-9568-\mathrm{x}$.

Storey AE, Zeigler TE. 2016. Primate paternal care: interactions of biology and experience. Horm Behav 1 (77): 260-271. DOI: 10.1016/j.yhbeh.2015.07.024.

Teichroeb JA, Sicotte P. 2008. Infanticide in ursine colobus monkeys (Colobus vellerosus) in Ghana: New cases and a test of the existing hypotheses. Behaviour 145 (6): 727-755. DOI: $10.1163 / 156853908783929160$.

Townsend SW, Slocombe KE, Thompson ME, Zuberbühler K. 2007. Female-led infanticide in wild chimpanzees. Curr Biol 17 (10): 355356. DOI: 10.1016/j.cub.2007.03.020.

Van Schaik CP, Van Noordwijk MA. 2019. Infanticide. In: Encyclopedia of Animal Behavior (Issue January, pp. 484-489). DOI: 10.1016/B978-0-12-809633-8.20703-6.

Wiens F. 2002. Behavior and ecology of wild slow lorises (Nycticebus coucang): Social organization, infant care system, and diet. Bayreuth University.

Wiens F, Zitzmann A. 2003. Social structure of the solitary slow loris Nycticebus coucang (Lorisidae). J Zool 261 (1): 35-46. DOI: 10.1017/S0952836903003947.

Winarti I. 2011. Habitat, Population and Distribution of the Javan slow loris (Nycticebus javanicus Geoffroy 1812) in Talun Tasikmalaya and Ciamis, West Java. IPB University, Bogor. [Indonesian]

Wirdateti. 2012. Distribution and habitat of the Javan slow loris (Nycticebus javanicus) in the vegetable plantation area, Mount Papandayan, Garut Regency. Berita Biologi 11 (1): 111-216. DOI: 10.14203/beritabiologi.v11i1.1887. [Indonesian]

Yao H, Yu H, Yang B, Yang W, Xu H, Grueter CC, Li M, Xiang Z. 2016. Male infanticide in the Golden snub-nosed monkey (Rhinopithecus roxellana), a seasonally breeding primate. Int J Primatol 37 (2): 175 184. DOI: $10.1007 / \mathrm{s} 10764-016-9892-2$ 